Jurnal Konstruksi Hukum | ISSN: 2746-5055

Vol. 2, No. 1, Januari 2021 Hal. 15-18 | Tersedia online di https://www.ejournal.warmadewa.ac.id/index.php/jukonhum

DOI: https://10.22225/jkh.2.1.2960.15-18

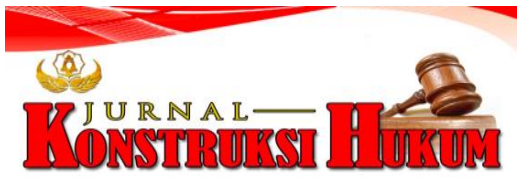

\title{
UPAYA PENCEGAHAN ANAK SEBAGAI KORBAN KEKERASAN SEKSUAL MELALUI DUNIA MAYA
}

\author{
Desak Ketut Linda Saraswati, A.A Sagung Laksmi Dewi, I Made Minggu Widyantara \\ Fakultas Hukum Universitas Warmadewa, Denpasar-Bali, Indonesia
}

\begin{abstract}
Abstrak
Semenjak dalam kandungan anak memiliki harkat dan martabat sebagai manusia seutuhnya yang diberikan oleh dari Tuhan Yang Maha Esa. Anak yang terlahir harus mendapatkan hak-hak nya tanpa anak tersebut meminta. Anak bagian dari generasi penerus cita-cita bangsa mempunyai peran strategis dalam menjamin eksistensi bangsa dan Negara dimasa yang akan datang. Kekerasan seksual terhadap anak saat ini tidak hanya terjadi secara fisik namun telah merambah di dunia maya. Hal ini karena mudahnya mengakses dunia maya khususnya media sosial oleh berbagai kalangan mulai dari anak-anak remaja dewasa bahkan orang tua. Penelitian ini menggunakan metode hukum normative yaitu suatu penelitian kepustakaan untuk mendapatkan bahan - bahan hukum. Hasil analisis menunjukan bahwa pencegahan yang dapat dilakukan melalui upaya preventif dan upaya represif. Upaya preventif melalui lingkungan keluarga yang menerapkan program 18-21 yang artinya pada pukul 18.00 sampai pukul 21.00 waktu anak dan orang tua untuk berdialog dan berinteraksi dimana yang pertama kali diterapkan di Kota Padang. Selain orang tua agar dapat memberikan waktu dan perhatian lebih terhadap anak. Upaya represif adalah dengan penindakan pelaku kekerasan seksual terhadap anak melalui dunia maya sesuai dengan peraturan perundang-undangan yang berlaku agar pelaku memiliki efek jera serta tidak kembali mengulanginya di lain hari.
\end{abstract}

Kata Kunci: Kekerasan seksual, Kejahatan dunia maya, Korban seksual, Pencegahan seksual

\begin{abstract}
Since being in the womb, the child has dignity as a whole human being given by God Almighty. A child who is born must get his rights without the child asking. Children who are part of the next generation with the ideals of the nation have a strategic role in ensuring the existence of the nation and state in the future. Sexual violence against children today does not only occur physically but has penetrated cyberspace. This is because it is easy to access cyberspace, especially social media, by various groups ranging from children, adolescents and even parents. This study uses the normative legal method, namely a library research to obtain legal materials. The results of the analysis show that prevention can be done through preventive and repressive measures. Preventive efforts through a family environment that implements the 18-21 program, which means that at 18.00 to 21.00 the time for children and parents to have dialogue and interaction, which was first implemented in Padang City. Besides parents, so that they can give more time and attention to children. Repressive measures are taking action against perpetrators of sexual violence against children through cyberspace in accordance with applicable laws and regulations so that the perpetrators have a deterrent effect and do not repeat it on another day.
\end{abstract}

Keywords: Cyber Crime, Sexual victims, Sexual prevention, Sexual violence

\section{PENDAHULUAN}

Berdasarkan UUD NKRI 1945 No 4 Tahun 1979 mengenai terjaminnya kesejahteraan pada anak didalamnya terkandung makna bahwa arti anak ialah masyarakat yang belum menginjak umur 21 tahun dan belum pernah menikah (Huraerah, 2007). Perlindungan hukum bagi anak sangatlah berbeda dari perlindungan pada umumnnya yang biasanya berlaku bagi orang dewasa. Karena dari segi fisik dan mental anak-anak masih dianggap belum mampu dan cakap. Maka dari hal tersebut Negara Indonesia memerlukan peraturan khusus mengenai perlindungan yang berlaku untuk anak-anak.

Hak-hak pada anak yang wajib di berikan pada anak tersebut memerlukan jaminan untuk mensejahterakan anak dalam membuka peluang pada anak tersebut untuk bertumbuh secara fisik mental social dan dalam tingkah lakunya dari hal ini maka anak memerlukan upaya- upaya perlindungan apabila mereka tidak mendapatkan hal yang semestinya tanpa ada perlakuan yang mendiskriminatifnya. Meskipun demikian perlindungan terhadap anak masih menjadi masalah sentral. Salah satu fenomena yang menjadi perhatian besar tidak hanya di Indonesia bahkan juga masyarakat internasional. Masalah anak banyak terjadi yaitu adanya tindakan kekerasan seksual terhadap anak 
yang dapat berupa kekerasan fisik atau psikologi. Permasalahan anak pada dewasa ini yang dilakukan melalui dunia maya akibat perkembangan yang telah terjadi dalam system elektronik maka permasalah yang biasanya ada berkaitan dengan anak ialah kekerasan seksual. Permasalahan tersebut dianggap cukup serius dan memerlukan cara menanggulanginya agar tidak terjadi secara terus menerus.

Kekerasan seksual pada anak adalah salah satu persoalan yang memiliki sifat universal karena kekerasan seksual pada umumnya mengandung norma yang diketahui oleh masyarakat dan tidak memiliki nilai keadilan. Apabila seorang anak telah mengalami kekerasan seksual maka ia mengalami masa yang sulit karena setiap orang mengetahui bahwa ia telah mengalami kekerasan seksual ataupun kesulitan lainnya yang timbul dari media televisi penegak hukum aparat hukum teman serta keluarga. Dari kekerasan seksual yang telah dialami oleh anak sebagai korban yang terjadi dalam lingkungan keluarga maka secara logika dapat juga terjadi pada lingkungan yang lebih luas yakni lingkungan bermasyarakat.

Tindakan seksual terhadap anak saat ini tidak hanya terjadi secara fisik namun telah merambah di dunia maya. Hal ini karena mudahnya mengakses dunia maya khususnya media sosial oleh semua kalangan. Dengan mudahnya mengakses dunia maya ini memberikan dampak baik maupun buruk. Dampak baik yang didapat dari dunia maya yaitu memudahkan menggali informasi berkomunikasi dengan orang yang jaraknya sangat jauh dan dapat juga digunakan sebagai media untuk menjalankan bisnis. Selain itu dunia maya juga dapat memberikan dampak negatif seperti banyak terjadi tindak pidana melalui dunia maya misalnya penipuan hoax bahkan kekerasan pada anak yang diawali dengan perkenalan hingga kekekerasan seksual melalui media masa sering terjadi belakangan ini.

Berdasarkan ketentuan Pasal 3 UU ITE penggunaan teknologi informasi dan transaksi elektronik di lakukan dalam aturan yang memiliki kepastian hukum itikad baik dan kebebasan memilih teknologi atau netral teknologi. Serta dalam Pasal 27 mengenai pelanggaran kesusilaan dari nilai yang semestinya dimanfaatkan dan digunakan dalam mengakses dan mendistribusikan pada media elektronik tersebut.

Berdasarkan aturan tersebut memiliki tujuan untuk menjamin dan menciptakan rasa aman dan kepastian hukum bagi anak yang menjadi korban serta dalam aturan tersebut menjadi dasar dalam bertindak dan menangani apabila ada permasalahan seperti itu lagi dan dasar dalam upaya menanggulangi kekerasan seksual pada anak. Selain itu lingkungan masyarakat yang baik akan membantu mengurangi kemungkinan terjadinya kekerasan seksual pada anak. Namun, yang jauh lebih penting adalah dalam lingkungan keluarga yang merupakan lingkungan terkecil dalam mengawasi anak dalam pergaulan serta dalam menggunakan media sosial dengan bijak. Oleh karena itu, cara ataupun upaya yang dapat dilakukan dalam penanggulangan tindak kekerasan seksual pada anak ini bukan hanya dari orang tua dan lingkungan bermasyarakat tetapi dibutuhkan juga peran pemerintah dalam perlindungan terhadap korban kekerasan yang pada kasus ini adalah anak dengan dibuatnya peraturan yang didalamnya memuat kepastian perlindungan hukum seperti adanya KPAI, UUPA dan pembentukan Kota Layak Anak.

Berdasarkan uraian latar belakang di atas peneliti menemukan adanya kekaburan norma terhadap maraknya kasus kekerasan seksual terhadap anak melalui media sosial yang menandakan bahwa peraturan perundang-undangan yang ada belum efektif dalam memberikan efek jera terhadap pelaku. Oleh karena itu, penelitian ini bertujuan untuk menganalisis upaya yang dilakukan untuk menanggulangi tindak kekerasan seksual terhadap anak sebagai korban melalui dunia maya dan mengetahui bentuk perlindungan hukum terhadap anak sebagai korban kekerasan seksual tersebut.

\section{METODE PENELITIAN}

Pencarian informasi secara normatif berpatokan pada peraturan pemerintah yang berfokus pada anak sebagai objeknya dan analisis dalam Informasi yang didapat secara konseptual berkaitan dengan penulisan ini. Penelitian hukum normatif adalah hukum kepustakaan yang mengacu pada Norma Hukum yang terdapat dalam peraturan Perundang-undangan. Penulis dalam menyelesaikan skripsi dengan tidak menyimpang dari hukum positif dan Penelitian melalui permasalahan yang dipaparkan diatas. Pendekatan perundangan - undangan adalah melakukan suatu penelitian dengan berpatokan pada undang - undang sebagai dasar penulisan skripsi. Pendekatan kasus dilakukan guna melihat mencatat dan memahami permasalahan yang diangkat dalam skripsi ini dengan tidak keluar dari zona hukum positif. Untuk mendapatkan merumuskan dan menganalisis bahan hukum ilmiah ini 
memerlukan metode penelitian sitematis dan terarah serta konsisten. Penulis meneliti kasus ini menggunakan metode normatif dan kualitatis dimana dalam pengerjaannya penulis menelaah isu hukum dengan didasari peraturan - peraturan hukum di Indonesia (Ahmad, 2008). Segala sesuatu yang berkaitan tidak lepas dari patokan dasar - dasar hukum yang berlaku di indonesia dan dari penelitian tersebut penulis dapat mengambil judul Upaya Pencegahan Anak Sebagai Korban Kekerasan Seksual Melalui Dunia Maya.

Kegunaan dari penelitian hukum normatif ini adalah untuk menjelaskan bagaimanakah hukumnya mengenai masalah tertentu. Yakni menggunakan berbagai data sekunder seperti peraturan perundang - undangan teori hukum dan dapat juga berupa pendapat para sarjana (Sunaryatio, 2006).

Teknik pengumpulan bahan hukum yang penulis gunakan dalam penulisan ini adalah Teknik kartu (card system). Menurut Soekanto \& Mamudji (2018) teknik kartu yaitu dengan membuat catatan - catatan baik berupa kutipan langsung yang diperoleh dari buku - buku artikel - artikel dan peraturan perundang-undangan yang berkaitan dengan permasalahan yang dibahas. Kartu yang perlu disiapkan yaitu kartu kutipan yang dipergunakan untuk mencatat atau mengutip data beserta sumber dari mana data tersebut diperoleh (Nama pengarang atau penulis) judul buku atau artikel impresum halaman dan lain sebagainya.

Berhubungan dengan penelitian ini cara menganalisis dengan secara deskriptif - analisis yakni menunjukkan gejala yang terjadi pada lingkungan penelitian terhadap suatu kasus yang diteliti dengan melakukan pendekatan dengan tertata dan ujungnya menghasilkan suatu data yang deskriptif.

\section{HASIL DAN PEMBAHASAN}

Kekerasan seksual di dalam system elektronik adalah tindakan kekerasan yang dilakukan tanpa melakukan kontak langsung dengan korban atau anak. Tindak kekerasan seksual ini tidak memberikan kerugian secara fisik kepada anak melainkan memberikan kerugian secara psikis terhadap anak. Karena tindak kekerasan seksual ini dapat berupa penyebaran foto-foto korban yang tidak pantas serta dapat pula berupa video (Fakih, 2010). Anak yang masih belum matang secara emosional mendapatkan guncangan psikologi yang sangat besar dan lebih sulit untuk memulihkan kembali kondisi si anak serta membutuhkan waktu yang cukup lama.

Upaya pencegahan merupakan proses cara tindakan menghindari agar tidak terlaksanakan. Atau dengan kata lain dengan cara atau upaya sebelum sesuatu tindakan terealisasikan dan menimbulkan sebuah tindakan yang melanggar peraturan. Upaya ini diharapkan agar kekerasan seksual terhadap anak melalui dunia maya dapat dihindari atau mengurangi terjadinya kekerasan seksual tersebut. Upaya pencegahan dapat dibagi menjadi tiga, yaitu:

1. Upaya preemtif

Upaya preemtif adalah upaya yang dilakukan pemerintah yang dilakukan sebelum tindak pidana terjadi yang dalam permasalahan ini dilakukan berupa penyuluhan mengenai dampak buruk yang ditimbulkan oleh dunia maya kepada anak selain itu kemenkominfo telah memblokir 542 ribu konten- konten pornografi yang ada di dunia maya khususnya media sosial kemenkominfo juga terus meningkatkan kerja sama dengan Polri khususnya dalam bidang Cyber Crime demi mencegah kekerasan seksual terhadap anak yang terjadi melalui dunia maya (Amelia R, 2017).

2. Upaya Preventif

Upaya preventif ditekankan pada mengurangi kesempatan untuk dilakukannya tindak kekerasan seksual. Dalam hal ini mengarah pada pencegahan dari segi lingkungan keluarga yang dimana menerapkan program 18-21 yang menitik beratkan pada pendampingan orang tua terhadap anak pukul 18.00 hingga pukul 21.00 dengan tidak menggunakan telepon televisi dan media lainnya agar orang tua lebih dekat kepada anak. Jika dilihat sekilas program 18-21 ini tidak memiliki keistimewaan namun memiliki manfaat berkelanjutan dalam pembentukan karakter anak.

3. Upaya Represif

Upaya represif ialah suatu dasar untuk menindak lanjuti pelaku kekerasan dengan berpedoman pada peraturan yang berkaitan misalkan kasus tindak kekerasan seksual terhadap anak melalui dunia maya. Dengan penerapan peraturan dan sanksi terhadap pelaku diharapkan agar pelaku memiliki efek jera dan tidak mengulangi kembali perbuatannya serta masyarakat lainnya tidak memiliki niat untuk melakukan hal yang sama. 


\section{SIMPULAN DAN SARAN}

\section{Simpulan}

Upaya yang dilakukan untuk mencegah dan menanggulangi tindak kekerasan seksual terhadap anak ialah peraturan mengenai larangan dilakukannya kekerasan seksual pada anak melalui dunia maya yang harus lebih diberatkan lagi. Pencegahan anak sebagai korban kekerasan seksual melalui dunia maya diperlukan melalui upaya preventif dan represif. Upaya preventif melalui lingkungan keluarga yang menerapkan program 18-21 yang artinya pukul 1800 sampai 2100 waktu anak dan orang tua untuk berdialog dan berinteraksi dimana yang pertama kali diterapakan di Kota Padang. Selain orang tua agar dapat memberikan waktu dan perhatian lebih terhadap anak. Upaya represif adalah dengan penindakan pelaku kekerasan seksual terhadap anak melalui dunia maya sesuai dengan peraturan perundang - undangan yang berlaku agar pelaku memiliki efek jera serta tidak kembali mengulangi perbuatannya dikemudian hari. Kemudian, perlindungan hukum yaitu dengan menerapan peraturan dan sanksi terhadap pelaku diharapkan agar pelaku memiliki efek jera dan tidak mengulangi kembali perbuatannya serta masyarakat tidak memiliki niat untuk melakukan tindak kekerasan seksual terhadap anak. Perlindungan hukum terhadap korban tindak kekerasan seksual tidak hanya tugas dari aparat penegak hukum melainkan pula tanggungjawab masyarakat guna membantu memulihkan kondisi korban dalam aktivitas bermasyarakat.

\section{Saran}

Melalui penelitian ini diharapkan kepada masyarakat secara umum, jika ada peristiwa yang mengarah tindak kekerasan segera melapor ke orang tua atau pihak berwajib karena dalam lingkungan anakanak masyarakatlah yang lebih tahu atau melihat secara langsung kekerasan tersebut. Selanjutnya, kepada pemerintah agar diperhatikan lagi perundang-undangan tentang anak dan menjatuhkan hukuman seberat-beratnya terhadap pelaku kekerasan seksual pada anak. Terakhir, kepada aparat penegak hukum agar bisa menerapkan hukum tanpa pandang bulu sesuai dengan peraturan yang berlaku.

\section{DAFTAR PUSTAKA}

Ahmad, B. (2008). Metode Penelitian Hukum. Bandung: Pustaka Setia.

Amelia R, M. (2017, September 18). Kominfo Blokir 542 Ribu Gambar Berkonten Pornografi di Medsos. Detiknews.

Fakih, M. (2010). Analisis Gender dan Transformasi Sosial (13th ed.). Yogyakarta: Pustaka Pelajar.

Huraerah, A. (2007). Kekerasan terhadap Anak. Bandung: Nuansa Aulia.

Soekanto, S., \& Mamudji, S. (2018). Penelitian Hukum Normatif: Suatu Tinjauan Singkat (18th ed.). Jakarta: Rajawali Pers.

Sunaryatio, H. (2006). Penelitian Hukum di Indonesia pada Akhir Abad Ke-20. Bandung: Alumni. 